\title{
Subglottis Neoplasm
}

National Cancer Institute

\section{Source}

National Cancer Institute. Subglottis Neoplasm. NCI Thesaurus. Code C4426.

A benign or malignant neoplasm that affects the subglottic area of the larynx. 